Universal Decimal Classification (UDC) number 613, 614

\title{
ACUTE ISSUES OF THE METHODICAL SUPPORT OF HEALTH RISK ASSESSMENT IN ENSURING PRODUCT SAFETY: FOREIGN EXPERIENCE AND CUSTOMS UNION PRACTICE
}

\author{
N.V. Zaitseva, P.Z. Shur \\ FBSI "Federal Scientific Center for Medical and Preventive Health Risk Management Technologies", Russian \\ Federation, Perm, 82 Monastyrskaya St., 614045
}

\begin{abstract}
Analysis of methodological support of safety assessment for products (goods) has shown that public health risk criteria are widely used to assess chemical and microbiological hazards of food products. At this, in the development of product risk assessment methodology, it is appropriate to use the accumulated experience in assessing the risk associated with exposure to environmental factors. The existing methodological approaches to assessment of product safety in the practice of the Customs Union should be supplemented with the assessment of evolution of the risk associated with the exposure to diverse factors intrinsic to production, with the account of responses of varying severity, as well as with quantitative assessment of individual and population health risks in case of non-compliance with safety requirements.
\end{abstract}

Key words: product safety, methodological approaches, health risk assessment, Customs Union.

In most countries and international organizations, the concept of risk assessment is considered as the main mechanism for development of policies, strategies and determination of priorities of the actions intended to achieve maximal, economically reasonable reduction of negative impact on public health. The concept of public health risk assessment under conditions of exposure to chemical, physical and biological agents, is essential in terms of the legislation concerning product safety and public health protection, both in the Customs Union member states and in the rest of the international community. [1] In global practice, methodological aspects of public safety maintenance, including use of health risk criteria, are well represented both in terms of environmental factors, and in terms of products. To the greatest extent it concerns chemical hazards.

A complete scheme of public health risk assessment under conditions of exposure to chemical hazards, considers four stages of this process:

- Hazard Identification, which includes qualitative determination of the weight of evidence concerning the ability of a chemical agent to cause some harmful effects in humans;

- Exposure Assessment is identification and assessment of quantitative and qualitative severity, frequency, duration and routes of exposure;

(C) Zaitseva N.V., Shur P.Z., 2013

Zaitseva Nina Vladimirovna - Professor, DSc in Medicine, Fellow of the Russian Academy of Medical Sciences, Director (e-mail: znv@fcrisk.ru; tel.: 8 (342) 237-25-34).

Shur Pavel Zalmanovich - Professor, DSc in Medicine, Secretary of the Academic Council (e-mail: shur@fcrisk.ru, tel/fax: 8 (342) 237-25-34, 8 (342) 238-33-37). 
- Dose-Response Assessment, quantitative characterization of toxicological information and determination of a relationship between the pollutant dose (concentration), the population is exposed to, and the incidence of adverse effects in the exposed population;

- Risk Characterization, integration of data obtained during all previous stages of investigation, with the aim of quantitative and qualitative risk assessment and identification and evaluation of the relative importance of public health concerns.

Analysis of the basic documents concerning risk assessment under conditions of exposure to chemical agents, has shown that in some of them the presented health risk assessment methodology complies exactly with the foregoing algorithm [3, 9, 13, 23, 39, 40], while, it should be noted, that in the others, including the obligatory stages of hazard identification and risk characterization, variation in the stages of risk assessment is demonstrated, although the goals of their implementation are maintained. Thus, when assessing health risks resulting from the exposure to chemical agents coming from food products (food additives, chemical contaminants, residual amounts of pesticides and veterinary drugs), in all cases the Hazard Characterization is an obligatory step of such assessment, which results, in essence, in evaluation of the "dose-response" relationship [24, 33, 35, 41]. Step by step algorithms of assessment of health risk posed by food products, including dietary supplements, associated with the presence of residues of veterinary drugs, chemical pollutants, pesticides, microbiological hazards in these food products, are provided in the Food and Agriculture Organization of the United Nations (FAO)/World Health Organization (WHO) Guidance on risk assessment [24]. In the context of assessment of microbiological risk of food products for human health the procedure includes a series of sequential actions, such as Hazard Identification, Hazard Characterization, Exposure Assessment and Risk Characterization [10, 11, 16, 38].

Methodological approaches to assessment of health risks imposed by physical hazards of the products, are virtually not described in the literature, however, basic elements of such assessment and a sufficient number of parameters that can be used in product safety analysis are presented in the methods for the assessment of environmental hazards $[2,5,6,15,19,20,22$, 30]. It should be noted, that despite some differences in the algorithm, the stages of such assessment are similar to the hazard identification, exposure assessment, evaluation of the "doseresponse" relationship and risk characterization.

Hazard Identification is the first step in the health risk assessment procedure and is most often interpreted as a process of identification of potential health hazards (of chemical, microbiological or physical nature) and the ability of some factor to cause some particular harmful effects in humans. The hazard identification step is performed in the form of a screening 
and involves identification of all possible health risk factors, characterization of their potential adverse effects and assessment of scientific evidences indicating the development of these effects in humans; characterization of conditions and routes of exposure; and characterization of a potential exposure group. Besides the fact that the hazard identification represents a step of the public health risk assessment procedure, it can be carried out to identify products, which need to be labelled as "dangerous" or to select animal species appropriate for subsequent studies $[9,23$, $40,41]$.

For chemical hazards contained in food products, including nutritional supplements, contaminants coming from environmental objects (e.g., mercury, dioxins), natural food toxicants (such as glycoalkaloids in potatoes, aflatoxins in peanuts), residual amounts of pesticides and veterinary drugs, a detailed hazard identification with determination of all possible adverse health consequences which occur in the food product consumers should also be carried out.

The leading criteria for selection of the priority chemicals include their content in products, the number of consumers potentially exposed, high stability, bioaccumulation ability, ability to cross-media distribution, and toxic properties [33].

When conducting microbiological risk assessment, several approaches to hazard identification may be applied, depending on the purpose of microbiological risk evaluation. In cases when microbiological risk assessment is used to study public health issues, the main focus concerns the disease and its possible outcomes. When microbiological risk assessment is performed during analysis of exposure of certain food products to hazard factors, the main outcome of the hazard identification step is the determination of pathogens which might be distributed with the test food product. As part of the development of management solutions for determining the need for and selection of the best place for implementation of control measures, as well as for comparison of different approaches for the disease prevention/control and establishment of hygienic standards, the hazard identification includes an assessment of microorganism properties which ensure its transmission with the food, and its ability to cause a disease. According to the results of the hazard identification in the case of microbiological risk assessment, the following parameters are determined: the list and characteristics of the priority microbial contaminants that are potentially hazardous to human health when enter the organism via one of the assessed routes of entry, and of the food products that may be contaminated by these hazards; susceptible populations and subpopulations, as well as the risk profile layout developed based on previous published studies [28, 29].

Analysis of methodological documents concerning health risk assessment has shown a significant difference in the procedure of hazard identification during risk assessment for cases of 
exposure to chemical and microbiological factors. Thus, it is believed that any chemical agent, when present in a sufficient amount, is able to cause certain harmful side effect on the health. In addition, one and the same chemical agent may be associated with several different adverse health effects which are not necessarily manifested under the investigated level of exposure. The ability of pathogens to multiply is the reason due to which even small baseline levels of pathogens can lead to the development of a disease. For this reason, during the hazard identification the main issue to be addressed is determination of the presence of a pathogen, rather than the health effect associated with its presence.

At the stage of identification of a human health hazard imposed by products (goods), it is reasonable to carry out an integral risk evaluation, with the account of all the information received and verification of possible exposure scenarios with estimation of exposure levels of each risk factor for each scenario [4]. As a result of this assessment, the sampling of scenarios is performed, for which there is no effect leading to adverse effects. For these scenarios, the need for full implementation of the procedure of risk evolution assessment is absent. Additional criteria for exclusion of scenarios from the risk evolution assessment procedure at the next stages include: small number of risk factors, the limited available data on the exposure and effects of exposure to risk factors.

The stage of evaluation of the "exposure-effect (response)" relationship involves the determination of causality of an adverse effect developed under the influence of the factor being studied, determination of the no-effect levels for factors with defined thresholds and identification of parameters of intensity of the effect increase with the increase of the exposure above these levels, as well as for factors which are supposed to have a non-threshold action.

In addition, the investigation of the ,dose-response” relationship serves as a basis for determination of the toxicity parameters which are subsequently used for risk characterization.

In the context of assessment of the risk associated with the exposure to chemicals, evaluation of the „dose-response" relationship is regarded as a process of quantitative characterization of toxicological information and determination of a link between the dose (concentration) of a factor tested and the incidence of harmful effects in the exposed population $[9,16,23,33,34]$. The data used to determine the "exposure-response" relationship, include the results of animal studies of toxicological issues, clinical studies of exposure, as well as conclusions of epidemiological studies that have the highest priority.

Chemical substances are characterized by a wide range of harmful effects, but in the risk assessment methodology it is common to focus on that adverse effect, which occurs under the lowest effective dose (critical effect, critical organs/systems). 
Safe levels of short-term exposure are estimated with the aim to prevent deaths, development of acute poisoning of varying severity or unpleasant subjective sensations resulting from short-term but intense contamination. These levels are usually estimated for conditions of short-term continuous chemical exposure with duration from 5-30 minutes to 6-8 hours and 24 hours. The most commonly used is the reference level of acute inhalation exposure of the population (acute reference concentration, ARfC) - maximum concentrations that do not cause adverse health effects in the majority of sensitive individuals within a specified averaging time of exposure.

To assess chronic non-cancer effects, a large number of levels, reflecting the daily exposure (intake) of the chemical over a lifetime, are used, including reference doses and concentrations $(R f D$ and $R f C$ ), acceptable daily intake $(A D I)$, tolerable daily intake (TDI), etc. Estimation of these values is usually based on the lowest observed adverse effect level (LOAEL) or no-observed adverse effect level (NOAEL). In the world practice, the preference is given to the risk assessment parameters obtained based on the results of epidemiological studies of benchmark (reference) levels (Benchmark Dose (BMD), Benchmark Concentration $(B M C)$ ).

When assessing a non-threshold effect, linearity between the experimentally obtained lowest dose and a zero dose is assumed, implying the existence of an amenable to calculation likelihood of adverse health response developed even at a very low dose. The numerical values of the likelihood are obtained by fitting one or several models to the range of experimental doses and extrapolation to lower levels of environmental exposure. The main parameter for assessment of the risk of exposure to a carcinogenic agent with non- threshold mechanism of action is a carcinogenic potency factor $(C P F)$ or a slope factor $(S F)$, which characterizes the degree of cancer risk increase with each one-unit increase of the exposing dose.

During the stage of hazard characterization performed for the assessment of health risk imposed by chemical contaminants coming with food products, the description and evaluation of the „dose-response” relationship is also performed for the most sensitive health response. In the presence of a threshold, based on the results of the hazard characterization, a safe intake level, an acceptable daily intake $(A D I)$ (for food supplements, veterinary drugs and pesticides) or a tolerable daily intake (TDI) (for chemical contaminants and chemical agents, materials coming in contact with food products) are determined.

Besides that, ADI may be estimated using benchmark doses and the uncertainty coefficient system. Usually the ADI values obtained using the foregoing methods, are not much different.

According to the Scientific report of EFSA International Frameworks Dealing with 
Human Risk Assessment of Combined Exposure to Multiple Chemicals [31], during hazard characterization performed for the conditions of the combined exposure to chemical substances, coming with food products, either a mixture of all chemical compounds together is analysed, or each agent is analysed separately, depending on the toxicity information available.

In the context of microbiological risk assessment, assessment of the „dose-response” relationship is carried out at the hazard characterization stage.

At this stage of the assessment of public health risk imposed by the exposure to factors of microbial nature, contained in food products, the relationships between the dose, virulence and manifestation (type, severity) of health responses are analysed in the susceptible population using statistical models for the "dose-response" relationship data obtained both for human and in animal experiments, with the account of routes of exposure, sources and method of preparation of a pathogen-containing material $[8,26,27]$.

For description of the "dose-response" relationship two hypotheses of the infectious process development have been proposed, the first one is related to the presence of a minimum infective dose and includes the development of threshold models, the second one considers the development of the infectious process in the presence of at least one colony forming unit (CFU) of a pathogen with the development of non-threshold models of exposure. The most commonly used in practice are the models, which are based on non-threshold assessment of infectious cases, i.e. accepting that even one microorganism can cause an infection; although, in some cases, when a threshold is defined, the thresholds models are considered, in which the criteria of minimal infectious doses (MID) of microorganisms are used [14].

When assessing chemical and microbiological risk, the steps of evaluation of the "doseresponse" relationship and of the hazard characterization are similar. For chemical agents this stage must necessarily include assessment of the "dose-response" relationship, while for biological agents - only in the presence of relevant data. In the case of microbiological risk assessment, health responses are less detailed and are often recorded as incidence of a disease at a certain level of exposure to an agent. The main aim in both cases is to determine the nature, severity and duration of the health response due to intake of a test agent.

During assessment of the health risk associated with noise exposure, the stage of analysis of the "dose-response" relationship provides for determination of the relation between the exposure and incidence, prevalence, type and severity of a presumed harmful effect in the population exposed to harmful noise. In accordance with the "Night noise guidelines for Europe" [30], the concept of estimation of thresholds of exposure using the NOAEL values, which is adopted in toxicology, is not applicable in the assessment of risk associated with noise exposure. 
In this case, a criterion for the threshold of the observed effect or the level of exposure, above which the effect occurs or the dependence of this effect on the dose can be established.

When assessing health risks imposed by the exposure to electromagnetic radiation (EMR), the assessments are based on the assumption of the existence of a threshold level of harmful exposure, below which adverse effects do not develop [6], however, in accordance with the Environmental Health Criteria [20], in addition to the threshold effects, during exposure to electromagnetic fields (EMF), there are also effects which are continuous with respect to the exposure.

The threshold effects which are dependent on the frequency of electromagnetic fields, are set for conditions of acute exposure of electrically excitable tissues, in particular the central nervous system (CNS). With respect to the effects resulting from chronic exposure, no exposure limits have been established [20].

The Exposure Assessment stage is focused on quantitative and/or qualitative detection of the intake of an agent entering the body due to its contact with different environmental objects, including food products. The exposure is referred to a contact of the body (receptor) with a chemical, physical or biological agent. The exposure can be expressed as the total amount of a substance in the environment (in mass units, for example, $\mathrm{mg}$ ), or as a value of exposure, i.e. a mass of a substance over a unit of time (e.g., $\mathrm{mg} /$ day), or as a value of exposure normalized to body weight $(\mathrm{mg} /(\mathrm{kg} \cdot$ day $)$. An important step of exposure assessment is generation of exposure scenarios (including the worst conditions), including description of specific conditions of exposure; a combination of facts, assumptions and conclusions concerning the exposure to the harmful factor tested.

Assessment of exposure to chemicals contained in food is carried out with regard to food additives, chemicals contaminating food products, residual amounts of pesticides and veterinary drugs, chemicals migrating into food from contacting materials. For all components of food products, the exposure assessment depends on the amount of contaminants (microorganisms, chemical substances) present in the product, the quantity of foods consumed (serving size), frequency of the intake of this kind of products. The existing methods for assessment of exposure to food-contaminating chemicals, combine the data on food products intake by the population (dietary patterns) with the data on the food load with the contaminants of chemical nature (concentration of chemicals) [12, 17, 32]. The exposure assessment methods used embrace the complete range of possible exposure scenarios - from "the worst" to the probabilistic-real assessment of exposure. There are two basic approaches to assessment of exposure to food-contaminating chemicals. These include: a deterministic (point assessment, 
multilevel approach) and probabolistic (probabilistic assessment). Currently most of the documents describe a stagewise (multilevel) approach for exposure assessment in relation to chemical hazards in food products $[12,25]$.

When identifying the microbiological risk, the exposure assessment aims to determine the actual or expected amount of pathogenic microorganisms entering the human body through the consumption of contaminated food, as well as to quantitatively and/or qualitatively assess the likelihood of presence of a pathogenic microorganism and its levels in a certain amount of food or water. During exposure assessment, the level of contamination of food products with an investigated microorganism is determined with the account of its life cycle, as well as time, frequency and duration of the exposure of a selected population to this pathogen [21, 39].

When conducting assessment of health risk imposed by noise exposure, the exposure evaluation involves identification of specified noise parameters at specified time and of the duration of its effects, as well as assessment of the daily weighted noise as a measure of population exposure to a harmful factor. The generally accepted main unit of the actual noise levels for risk assessment, is $L_{d e n}$ (equivalent daily weighted noise level), which may be estimated using day and night noise levels $[5,15,19]$.

In the context of assessment of health risk, related to the exposure to electromagnetic fields, the exposure evaluation includes determination of electromagnetic characteristics of the range of exposure at a specified time and the period of maintenance of certain levels of electromagnetic fields, as well as assessment of the weighted electromagnetic field level as a measure of consumer's contact with a harmful factor. The exposure assessment may be performed by theoretical calculations [6].

Risk Characterization is a stage, at which a qualitative risk assessment, calculation of indexes and a semi-quantitative and a quantitative risk assessment, as well as risk classification with evaluation is its tolerability, is performed. In methodological documents addressing the issues of production risk assessment, the most detailed description of Risk Characterization stage is for microbiological $[8,10,16,26-28,38]$ and chemical $[12,23,35,38,41]$ food hazards.

In accordance with the Codex Alimentarius Commission (CAC) document called "Principles and Guidelines for microbiological risk assessment" [16], risk characteristics are determined in the result of combination of hazard identification, hazard characterization and exposure assessment, in order to obtain a final risk assessment. Such risk characterization allows qualitative or quantitative assessment of the likelihood and severity of adverse effects that may occur in this population, including the description of uncertainties associated with these final assessments. This assessment may be performed through the comparison with independent 
epidemiological data that associate hazards with the prevalence of diseases.

In accordance with the methodological recommendations "Assessment of public health risk posed through exposure to microbial hazards contained in foods. Methodological fundamentals, principles and assessment criteria" [8], it is recommended to isolate two main components of risk characterization: determination and description. The process of risk determination includes description of the types and severity of adverse effects. The result of response characterization may be the likelihood of disease development upon intake of a certain amount of microorganisms. The second component of risk characterization (risk description) is carried out with regard to the nature, severity and outcomes of the disease case.

A joint publication of the World Health Organization (WHO) and the Food and Agriculture Organization of the United Nations (FAO) [38] describe qualitative, semiquantitative and quantitative risk characterization.

A qualitative risk assessment is proposed for preliminary screening studies to justify further risk assessment and determine the missing information for its quantitative assessment. Its main advantages include the following: the results are easier and faster to understand, among others by the decision-makers; it may be implemented in those cases, when a quantitative assessment cannot be performed due to the lack of data. The procedure of qualitative microbial risk assessment involves the data analysis with the assessment of their uncertainty, justification and the conclusion which contains the answers to the questions raised in accordance with the objectives of the risk assessment. A semi-quantitative microbiological risk characterization is performed using methodological approaches that are applied for qualitative risk assessment. However, ranking of the likelihood and frequency of exposure and its effects allows more adequate determination of the microbiological risk categories compared with a qualitative assessment. During semi-quantitative assessment, categorization of the likelihood and frequency of exposure for each microbiological risk factor is performed. A quantitative characterization of a microbiological risk can be carried out using probabilistic and deterministic models. During quantitative characterization of a microbiological risk, depending on the study tasks the likelihood of a disease development after an intake of a single standardized portion of a food product is analysed and/or a disease development after consumption of the food product over a certain period of time. The second approach is closer to deterministic models, as it assumes that the exposure may repeats with some frequency. The effect (response) can be registered both in the form of a disease, and in the form of indexes which take into account economic aspects (number of days of disability, QALY, etc.).

For quantitative characterization of food hazards, individual and population risks are 
calculated for a population. The individual risk is the likelihood of the fact that a random individual of the study population (subpopulation) will develop a disease due to infection after single consumption of a food product, after consumption during a certain period of time or during individual's lifetime, as well as the expected number of negative effects which occur in an individual after consumption of a certain amount (for example, $1 \mathrm{~kg}$ ) of a food product. As population risk indicators, the expected number of cases or the number of days of disability associated with the food products consumption in the population are used, or the likelihood of development of one case of a disease or death in the population within 1 year, etc.

For other types of products, the risk characterization is carried out mainly to justify the levels of exposure to factors unrelated to an unacceptable health risk. The United States Consumer Product Safety Commission (CPSC) gives the following description of the risk assessment process: "For purposes of this guidance, we are defining the risk as a likelihood of that fact that injury or damage is or can be caused by a substance, technology, or activity". Accordingly, as the result of risk characterization carried out by the experts of this commission, is considered determination of safety levels for chemical and other factors of production with regard to the criteria of consumers' health risk. [18] By product recall, the CPSC allocates three levels of risk characterization in order to determine the risk associated with a product posing a "substantial risk." The three classes of risk are based on two factors - the seriousness of the injury/disease and the likelihood of its origin. In the process of risk characterization the value of conditionally acceptable risk is used, which is the likelihood of an event, the negative effects of which are so insignificant that to achieve the benefit from a risk factor a person or a group of people or a society in general are ready to take that risk. Methodological approaches to quantitative characterization of non-cancer risk are based on the results of epidemiological studies [7].

Implementation of these methodological approaches involves, in the absence of relevant information concerning the no-effect level of chemical risk factor, determination of the benchmark exposure level with the subsequent creation of paired mathematical models "exposure-likelihood of response" for exposure values which are above benchmark levels. When characterizing the risk, calculated on the basis of the "exposure-response" relationship parameters obtained in epidemiological studies, it is necessary to take into account the correspondence of the periods of averaging of estimated exposure levels by those under which the respective criteria were established. However, chemical factors can simultaneously affect functions of multiple organs and systems, and a simultaneous exposure to several chemical factors is also possible. In this case for risk characterization the risk evolution models are 
applied.

Evolution models-based risk characterization is performed using a modified health risk index $(\tilde{R})$. The recommendation on the management of the health risk related to the problems resulting from chemical hazards, may be established taking into account the rating scale for $\tilde{R}$. The $\tilde{R}$ values less than 0.05 are referred to a negligible risk (acceptable, tolerable), not different from ordinary, everyday risks, the $\tilde{R}$ values of 0.05-0.35 - moderate risk, 0.35-0.6 - high risk, over 0.6 - very high risk. In addition, for chemical exposure also a reduction in the projected life expectancy of the population under given exposure conditions is estimated. The risk values reflect mainly a long term trend towards changes of the health indicators, which is formed in the case if all taken into calculation baseline conditions (e.g., a certain duration and intensity of the exposure, specific exposure factors, etc.).

Conclusions. Therefore, considering the harmonization with the international legislation and methodological support for its implementation for assessment of health risk for the Customs Union countries imposed by products (goods), it is advisable to outline the following stages:

- Hazard identification, including determination of risk factors, isolation of risk groups with indication of the most sensitive population subgroups, characterization of the effects (responses) resulting from the exposure to those risk factors, including characterization for the most sensitive population groups;

- assessment of the ,exposure-effect (response)" relationship including types and parameters of mathematic models, including the no-effect levels;

- exposure assessment, which involves exposure scenarios and a calculation of the intensity and duration of the exposure for each scenario;

- risk characterization, including calculation of individual and population health risk indicators, taking into account the simultaneous exposure to heterogeneous factors leading to the effects of varying severity under the exposure scenarios considered, assessment of the integral health risk imposed by products, risk classification and assessment of its compliance with an acceptable level.

To assess the risk, which products pose to a consumer health, it is recommended to use the existing methodological approaches, primarily those for the assessment of risk imposed by food products. These approaches should be completed with the assessment of integral risk associated with the exposure to heterogeneous factors of production, taking into account the responses of varying severity on the basis of evolutionary models. As the results of assessment of the health risk imposed by products, in addition to justification of product characteristics conforming to an acceptable risk level, the expected quantitative assessment of individual and 
population health risk which takes place in case of non-compliance with safety requirements, should also be considered.

\section{Referencs}

1. Zajceva N.V., Maj I.V. Pravovye aspekty ocenki riska dlja zdorov'ja naselenija pri obespechenii bezopasnosti tovarov: mirovoj zarubezhnyj opyt i praktika Tamozhennogo sojuza [Legal aspects of health risk assessment in ensuring the safety of goods: foreign experience and Customs Union practice]. Analiz riska zdorov'ju, 2013, no. 3, pp. 4-16.

2. Instrukcija 2.1.8.10-12-3-2005 po ocenke riska zdorov'ju naselenija ot vozdejstvija shuma $\mathrm{v}$ uslovijah naselennyh mest [Guidelines 2.1.8.10-12-3-2005 for health risk assessment of exposure to noise in populated areas]. Utverzhdeno glavnym sanitarnym vrachom Respubliki Belarus' ot 22 maja 2005 g. Available at: http://www.newsby.org/documents/razn/pos08/postn08656.htm.

3. Instrukcija po ocenke riska dlja zdorov'ja pri vozdejstvii himicheskih veshhestv 2.1.6.11-9-29-2004. Ocenka riska dlja zdorov'ja naselenija ot vozdejstvija himicheskih veshhestv, zagrjaznjajushhih atmosfernyj vozduh [Guidelines for health risk assessment of exposure to chemical substances 2.1.6.11-9-29-2004. Health risk assessment of exposure to chemical substances polluting ambient air]. Postanovlenie Glavnogo gosudarstvennogo sanitarnogo vracha Respubliki Belarus' ot 5 ijulja 2004 g. no. 63.

4. Zajceva N.V., Shur P.Z., Maj I.V., Kir'janov D.A. Metodicheskie podhody k ocenke integral'nogo riska zdorov'ju naselenija na osnove jevoljucionnyh matematicheskih modelej [Methodological approaches to integral health risk assessment based on mathematical evolutionary models]. Zdorov'e naselenija i sreda obitanija, 2011, no. 10, pp. 6-9.

5. Metodicheskie rekomendacii MR 2.1.10.0059-12. Ocenka riska zdorov'ju naselenija ot vozdejstvija transportnogo shuma [Methodical guidelines MR 2.1.10.0059-12. Health risk assessment of exposure to traffic noise]. Moscow: Federal'nyj centr gigieny i jepidemiologii Rospotrebnadzora, 2011. 40 p.

6. Metodicheskie rekomendacii MR 2.1.10.0061-12. Ocenka riska dlja zdorov'ja naselenija pri vozdejstvii peremennyh jelektromagnitnyh polej (do $300 \mathrm{GGc}$ ) v uslovijah naselennyh mest [Methodical guidelines MR 2.1.10.0061-12. Health risk assessment of exposure to alternating electromagnetic fields (up to $300 \mathrm{GHz}$ ) in populated areas]. Moscow: Federal'nyj centr gigieny i jepidemiologii Rospotrebnadzora, 2012. 29 p.

7. Metodicheskie rekomendacii MR 2.1.10.0062-12 Kolichestvennaja ocenka nekancerogennogo riska pri vozdejstvii himicheskih veshhestv na osnove postroenija jevoljucionnyh modelej [Methodical guidelines MR 2.1.10.0062-12. Quantitative assessment of non-carcinogenic risk of exposure to chemical substances based on building evolutionary models]. Available at: http://www.niid.ru/documents/ros/ukaz/86008/.

8. Ocenka riska zdorov'ju naselenija pri vozdejstvii faktorov mikrobnoj prirody, soderzhashhihsja v pishhevyh produktah. Metodicheskie osnovy, principy i kriterii ocenki: metodicheskie rekomendacii 2.1.10.0067-12 [Health risk assessment of exposure to factors of microbial origin contained in food products. Methodical basics, principles and criteria of assessment: methodical guidelines 2.1.10.0067-12]. Moscow: Federal'nyj centr gigieny i jepidemiologii Rospotrebnadzora, 2012.53 p.

9. R 2.2.1.10-1904. Rukovodstvo po ocenke riska dlja zdorov'ja naselenija pri vozdejstvii himicheskih veshhestv, zagrjaznjajushhih sredu obitanija [Guidelines $\mathrm{R}$ 2.1.10.1920-04. Guidelines for health risk assessment of exposure to chemical substances polluting the environment: approved by the Chief Medical Officer of the Russian Federation]. Utverzhdeno glavnym gosudarstvennym sanitarnym vrachom RF. Available at: http://base1.gostedu.ru/46/46715. 
10. Appendix II: Draft principles and guidelines for the conduct of microbiological risk assessment. Report of the thirty-first session of the Codex Committee on Food Hygiene. Orlando, United States: Codex Alimentarius Commission, WHO, 26-30 October 1998, pp. 35-42.

11. Application of risk analysis to food standard issues: report of the Joint FAO, WHO Expert Consultation, WHO. Geneva, Switzerland, 13-17 March 1995. 39 p.

12. Assessing Exposure from Pesticides in Food: A User's Guide. Canada: Pest Management Regulatory Agency Health, 2003. P. 38.

13. Assuring food safety and quality: guidelines for strengthening national food control systems. FAO Food and Nutrition Paper. FAO/WHO, 2003, vol. 76.80 p.

14. Benford D.J. Principles of risk assessment in food and drinking water related to human health. ILSI Europe Concise Monograph Series, Brussels: International Life Science Institute, $2001.34 \mathrm{p}$.

15. Burden of the disease from environmental noise. Quantification of healthy life years in Europe. WHO, 2011. 126 p.

16. CAC/GL-30. Principles and guidelines for the conduct of microbiological risk Assessment. Food Hygiene. Basic Texts. Codex Alimentarius, FAO, WHO, 1999, 2nd edition. pp. 53-63.

17. Consultations and Workshops: Dietary exposure assessment of chemicals in food: Report of a joint FAO/WHO consultation. Annapolis, Maryland, USA: WHO, 2-6 May 2005. $88 \mathrm{p}$.

18. CPSIA Status Report. Review of Metals in the Toy Safety Standard. ASTM F 963. 03/14/2012. USA: Consumer Product Safety Commission, 2012. 172 p.

19. Directive 2002/49/Ec Of The European Parliament And Of The Council of 25 June 2002 relating to the assessment and management of environmental noise. Official Journal of the European Communities, 2002, no. L189/12-L189/25. Available at: http://ec.europa.eu/environment/noise/directive.htm.

20. Environmental Health Criteria 137. Electromagnetic Fields (300 HZ TO 300 GHZ). WHO, 1993. Available at: http://www.inchem.org/documents/ehc/ehc/ehc137.htm.

21. Exposure assessment of microbiological hazards in food: guidelines. MRA Series. WHO, FAO, 2008, no. 7. Available at: http://www.who.int/foodsafety/publications/micro/mra7/en/index.html.

22. Extremely Law Frequency Fields. Environmental Health Criteria. WHO, 2007, no. 238. $543 \mathrm{p}$.

23. Food safety risk analysis - A guide for national food safety authorities. FAO food and nutrition paper. Rome: FAO, WHO, 2006, vol. 87. 50 p.

24. Food Safety Risk Analysis. Part I: An Overview and Framework Manual. Provisional Edition. Rome: FAO, WHO, 2005. 86 p.

25. Food Standards Australia New Zealand. Principles and Practices of Dietary Exposure Assessment for Food Regulatory Purposes. 2009. 104 p.

26. Framework for Science-Based Risk Assessment of Micro-Organisms Regulated under the Canadian Environmental Protection Act. Environment Canada and Health Canada, 1999. 20 p.

27. Hazard characterization for pathogens in food and water: guidelines. Microbiological risk assessment series. FAO, WHO, 2003, no. 3.76 p.

28. Microbial Risk Assessment Guideline. Pathogenic Microorganisms With Focus On Food And Water. The Interagency Microbiological Risk Assessment Guideline Workgroup, USDA, FSIS and EPA, 2012. $231 \mathrm{p}$.

29. Microbiological Risk Assessment in Food Processing. Ed. by Martyn Brown and Mike Stringer. CRC Press LLC, 2002. 301 p.

30. Night noise guidelines for Europe. WHO, 2009. $184 \mathrm{p}$.

31. Overview of the procedures currently used at EFSA for the assessment of dietary 
exposure to different chemical substances: scientific report of EFSA. EFSA Journal, Parma, Italy: European Food Safety Authority, 2011, vol. 9 (12), no. 2490, p. 33.

32. Principles and Methods for the Risk Assessment of Chemical in Food. Chapter 6. Dietary exposure assessment of chemicals in food. FAO/WHO, 2009, P. 95.

33. Principles and methods for the risk assessment of chemicals in food. Environmental Health Criteria. WHO, 2009, no. 240. Available at: http://www.inchem.org/documents/ehc/ehc/ehc240_index.htm.

34. Principles For The Assessment Of Risks To Human Health From Exposure To Chemicals: Environmental Health Criteria 210. WHO, 1999. Available at: http://www.inchem.org/documents/ehc/ehc/ehc210.htm.

35. Principles For The Safety Assessment Of Food Additives And Contaminants In Food. Environmental Health Criteria/Geneva: International Programme On Chemical Safety, WHO, 1987, no. 70. Available at: http:/www.inchem.org/documents/ehc/ehc/ehc70.htm.

36. Report From The Commission on Dietary Food Additive Intake in the European Union. EC, 2011.26 p.

37. Revised framework for microbial risk assessment: An ILSI Risk Science Institute Workshop Report. USA: International Life Sciences Institute, 2000. 27 p.

38. Risk Characterization of Microbiological Hazards in Food. MRA Series, WHO, FAO, 2009, no. 17. Available at: http://www.who.int/foodsafety/publications/micro/MRA17.pdf.

39. The Future of Risk Assessment in the European Union. The Second report on the Harmonisation of Risk Assessment Procedures. Brussels: Scientific Steering Committee, EU, 2003. $112 \mathrm{p}$.

40. The Report of the Scientific Steering Committee's Working Group on Harmonisation of Risk Assessment Procedures in the Scientific Committees advising the European Commission in the area of human and environmental health. First Report on the Harmonisation of Risk Assessment Procedures. Brussels: Scientific Steering Committee, EU, 26-27 October 2000, part 1. $173 \mathrm{p}$.

41. Updating the Principles and Methods of Risk Assessment: MRLs for Pesticides and Veterinary Drugs. Rome: FAO, WHO, 2006. 47 p. 